\title{
Biosynthesis of triangular-shape ZnO nanoparticles using Tecoma stans and its antimicrobial activity
}

Aayushi Biswas, ${ }^{a}$ Bishwajit Changmai, ${ }^{a}$ C. Vanlalveni, ${ }^{b}$ R. Lalfakzuala,${ }^{b}$ Soumitra Nath, ${ }^{c}$ Samuel Lalthazuala Rokhum ${ }^{* a, d}$

${ }^{a}$ Department of Chemistry, National Institute of Technology Silchar, Silchar 788010, Assam, India.

${ }^{b}$ Department of Botany, Mizoram University, Tanhril, Aizawl, Mizoram, 796001, India

${ }^{c}$ Department of Biotechnology, Gurucharan College, Silchar 788001, Assam, India

${ }^{d}$ Department of Chemistry, University of Cambridge, Lensfield Road, Cambridge CB2 1EW, UK.

*Corresponding authors e-mail address; rokhum@ @ che.nits.ac.in; Tel.: +91 3842 242915; Fax: +91 $3842-224797$

\section{Key words}

Biosynthesis; ZnO nanoparticles; Tecoma stans; Characterization; Antimicrobial activity.

\section{Highlights}

1. First report on the bioinspired synthesis of triangular-shape zinc oxide nanoparticles $(\mathrm{ZnO}-$ NPs) using Tecoma stans.

2. XRD investigation confirmed the formation of crystalline $\mathrm{ZnO}-\mathrm{NPs}$

3. TEM images displayed the triangular shape of the synthesized NPs

4. Photoluminescence studies of NPs displays a sharp emission of blue band at $447 \mathrm{~nm}$

5. The XPS spectrum revealed the presence of $\mathrm{Zn}$ and $\mathrm{O}$ in the NPs sample.

6. The synthesized $\mathrm{ZnO}-\mathrm{NPs}$ showed high antimicrobial activities 
Graphical abstract

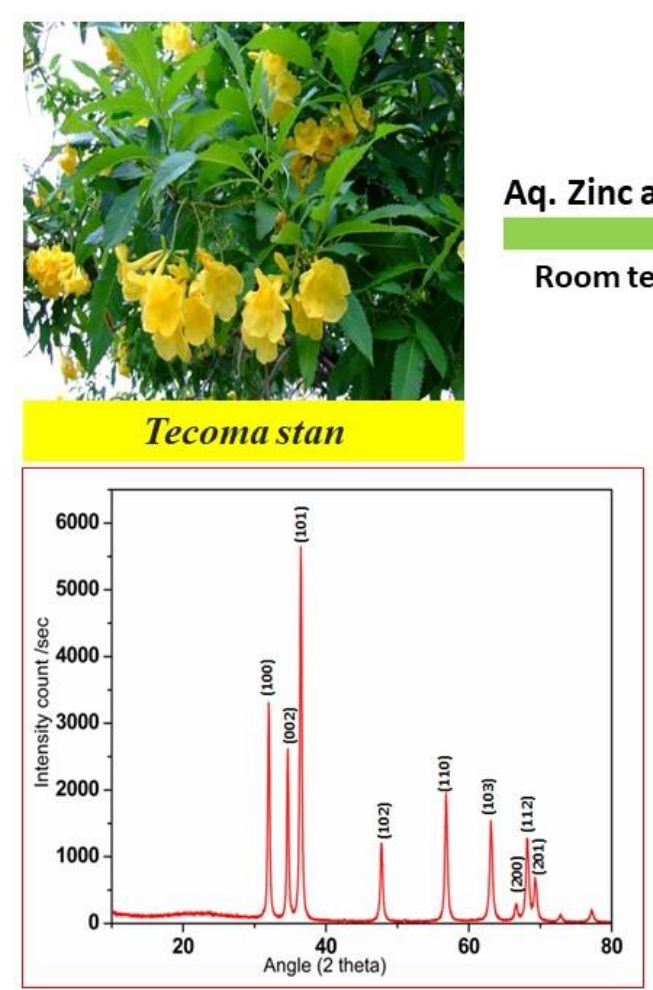

XRD pattern of ZnO-NPs

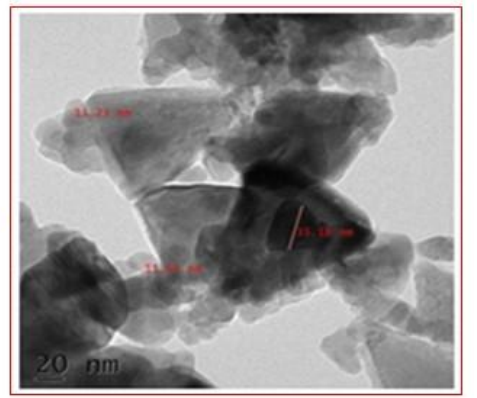

TEM image of ZnO nanoparticles

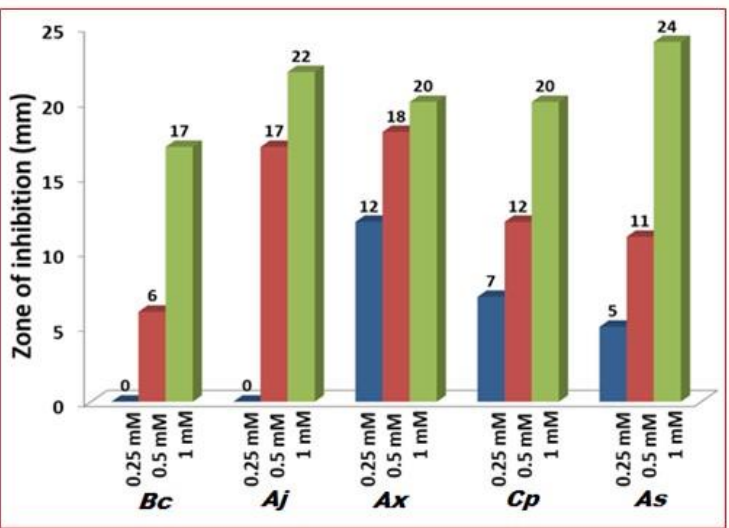

Antimicrobial activities of ZnO-NPs

\begin{abstract}
The present work reports the first green synthesis of zinc oxide nanoparticles (ZnO-NPs) using Tecoma stans leaf extract. The ZnO-NPs have been investigated by X-Ray Diffraction (XRD), Ultra Violet-Visible (UV-Vis), Scanning Electron Microscopy (SEM), Transmission Electron Microscopy (TEM) and Fourier Transform-Infra Red (FT-IR) analysis. XRD investigation confirms the crystalline structure of $\mathrm{ZnO}$. The TEM images show triangular shape ZnO-NPs with sizes running from 15-20 nm. The XPS spectrum revealed the presence of $\mathrm{Zn}$ and $\mathrm{O}$ in the sample. Photoluminescence studies of $\mathrm{ZnO}-\mathrm{NPs}$ displayed a sharp emission of blue band at $447 \mathrm{~nm}$ which is attributed to the defect structures in $\mathrm{ZnO}$ crystal. The presence of alcoholic, phenolic amide groups in the plant extracts is responsible for the formation of $\mathrm{ZnO}-\mathrm{NPs}$. The synthesized $\mathrm{ZnO}-$ NPs showed a very high antibacterial property against five bacterial strains such as Bacillus cereus,
\end{abstract}


Acinetobacter johnsonii, Achromobacter xylosoxidans, Achromobacter spanius and Chromobacterium pseudoviolaceum, with the highest zone of inhibition (ZOI) of $24 \mathrm{~mm}$ being shown against Achromobacter spanius strain. Further, the synthesized nanoparticles displayed excellent activities against four fungal strains, where a highest ZOI of $30 \mathrm{~mm}$ was observed against Penicillium citirinum, hence proving its high efficacy as antimicrobial agents.

\section{Introduction}

Nanotechnology is one of the most promising research areas in the modern science and technology. It deals with the particle having a one-dimensional size range of 1-100 nm [1]. In the last few decades, research on nanoparticles has developed rapidly due to their exceptional electronic [2],[3], catalytic [4],[5] [6],[7], optical [8], magnetic [9] and medicinal properties [10]. Presently, nanoparticles and nanomaterial's are finding its applications in various field such as molecular self-assembly [11],[12], medication [13],[14],[15], stainable power sources [16],ecological remediation [17] and so on. Fittingly, in recent years synthesis of numerous nanoparticles mainly precious metals such as gold, silver and platinum has been reported in literature. However, although these nanoparticles are very widely useful, their production involves the use of expensive precursors. Hence, researchers are looking for an alternative nanoparticles such as zinc oxide nanoparticles ( $\mathrm{ZnO}-\mathrm{NPs}$ ), which is more cost-effective and exhibited comparable activity to those of precious metal nanoparticles [18],[19],[20]. ZnO-NPs are known to exhibit outstanding applications in food packaging [21],[22], plant growth promoter [23], drug delivery [24],[25], anticancer [26], antimicrobial [27],[28] and degradation of toxic dyes in the environment [29]. Several chemical methods are reported in the literature for the synthesis of $\mathrm{ZnO}-\mathrm{NPs}$ [28]. However, in recent years, in search of an eco-friendly, mild and greener synthetic route, researchers have turned their attentions towards the synthesis of ZnO-NPs using various plant extracts and microbes [30],[19]. ZnO-NPs are largely non-toxic, semi-conducting materials possessing high stability, transparency and an excellent photocatalysts.

Review of literature revealed that both the chemical and physical properties of nanoparticles are dependent on their shape and size [31],[32], Hence, recent years witness an increasing interest in synthesizing nanoparticles of desired shape and size for a specific application [33],[34],[35],[36],[37]. In the recent past, shape-dependent activities of ZnO-NPs against microorganisms and enzymes has been reported where that the pyramidal shape ZnO-NPs shows 
higher activity compared to spherical shape nanoparticles as antimicrobial agents owing to their better geometrical match with the enzyme surface due to sharper apexes and edges[31]. Accordingly, owing to its close resemblance to pyramidal structure in terms of sharp apexes and edges, triangular shape $\mathrm{ZnO}-\mathrm{NPs}$ is of particular interest as it has potential to display higher shapedependent activities against common pathogenic microbes, compared to its spherical geometry counterparts. In the light of this, here we have demonstrated the green synthesis of triangular shape ZnO-NPs using Tecoma stans leaf extract as a reducing and stabilizing agent and investigated its application as an antimicrobial agents against several pathogenic microbes. The ZnO-NPs obtained were fully characterized by Ultraviolet (UV)-visible spectroscopy, Fourier transform infrared (FT-IR), Transmission electron microscopy (TEM), Energy dispersive X-ray spectroscopy (EDS) and X-ray diffraction (XRD), Scanning electron microscope (SEM), X-ray photoelectron spectroscopy (XPS) and Thermogravimetric analysis (TGA). The as-synthesized ZnO-NPs were studied to evaluate its efficacy as antimicrobial agents. From literature, majority of the green synthesis of ZnO-NPs obtained spherical shape nanoparticles, whilst preparation of triangular shape is rather rare [38]. To the best of our knowledge, this is the first report on the biosynthesis of triangular-shape $\mathrm{ZnO}-\mathrm{NPs}$ using Tecoma stans leaf extract.

\section{Experimental}

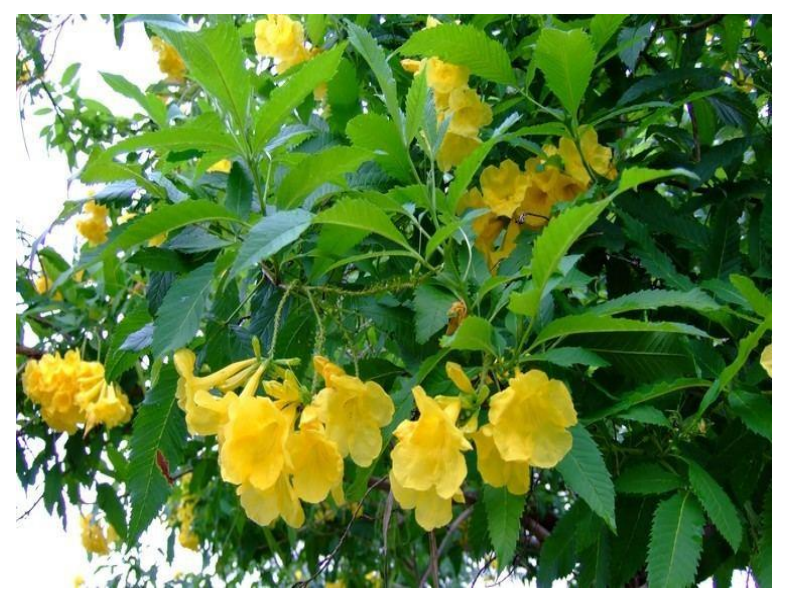

FIGURE 1. Tecoma stans plant

\subsection{Preparation of leaf extract}

The fresh Tecoma stans leaves used in the experiment were collected from NIT Silchar campus, Assam. Zinc Acetate dehydrate $90 \%$ pure was procured from HiMedia (India). $30 \mathrm{~g}$ of leaves was 
collected, washed 2-3 times with tap water followed by double distilled water to remove all the impurities present, air-dried and chopped to fine pieces. The chopped Tecoma stans leaves were then boiled with $100 \mathrm{ml}$ of distilled water for $30 \mathrm{mins}$ in a $500 \mathrm{~mL}$ round bottomed flask. The leaf extract obtained after boiling was then filtered using a Whatman filter paper no. 1. Then cooled and filtered, the filtrate leaf extract was then finally stored at $4{ }^{\circ} \mathrm{C}$ was further utilized for the synthesis of $\mathrm{ZnO}-\mathrm{NPs}$.

\subsection{Synthesis of $\mathrm{ZnO}-\mathrm{NPs}$}

$40 \mathrm{~mL}$ of the Tecoma stans leaf extract was added drop wise to the previously prepared zinc acetate $(2 \mathrm{mM})$ solution and stirred on a magnetic stirrer at room temperature for $3 \mathrm{~h}$. The preliminary $\mathrm{ZnO}$ formation was confirmed visually from color change of the reaction mixture from green to dark brown which was later confirmed b UV-Visible Spectrophotometer. The reaction mixture was then collected in test tubes and centrifuged at $4000 \mathrm{rpm}$ for 15-20 min and the dark brown precipitate obtained was finally washed with double distilled water, collected and oven dried over night at $60{ }^{\circ} \mathrm{C}$ to obtain the as-synthesized ZnO-NPs (before calcination). The dry precipitate of as-synthesized ZnO-NPs was then transferred to a ceramic crucible and calcined in a preheated furnace at $700{ }^{\circ} \mathrm{C}$ for $3 \mathrm{~h}$ to obtained a highly stable triangular shape $\mathrm{ZnO}-\mathrm{NPs}$, which were kept in an air tight container for further characterization. The $\mathrm{ZnO}-\mathrm{NPs}$ were found to be stable for 3-4 months.

\subsection{Screening of Antimicrobial Property of synthesized ZnO-NPs}

\section{Test microorganisms:}

In vitro antimicrobial screening includes 5 bacterial and 4 fungal strains. The bacterial strains includes Bacillus cereus strain SN_SA, Acinetobacter johnsonii strain SB_SK, Achromobacter xylosoxidans GCC582, Achromobacter spanius strain GCCSB1 and Chromobacterium pseudoviolaceum strain GCC-SO4, having NCBI-GenBank accession number MH482928, MH482927, KF031122, MK000623 and MH109305 respectively. The laboratory fungal isolates includes Aspergillus niger, Penicillium citirinum, Fusarium oxysporium, Candida albicans. Bacterial strains were grown and maintained on nutrient agar medium, while fungi were maintained on potato dextrose agar (PDA) medium. 


\section{Results and discussion}

\subsection{UV-Visible spectra analysis}

Figure 6.2 shows the UV-Vis spectra of as-synthesized $\mathrm{ZnO}-\mathrm{NPs}$ obtained from the reaction of Tecoma stans leaf extract and silver nitrate solution. A strong absorption band in the region 350$415 \mathrm{~nm}$ with a sharp peak at $385 \mathrm{~nm}$ confirmed the formation of ZnO-NPs. The absorption peak at $385 \mathrm{~nm}$ corresponds to energy gap value $3.26 \mathrm{eV}$, similar to the value reported for $\mathrm{ZnO}$ nanorods [39].

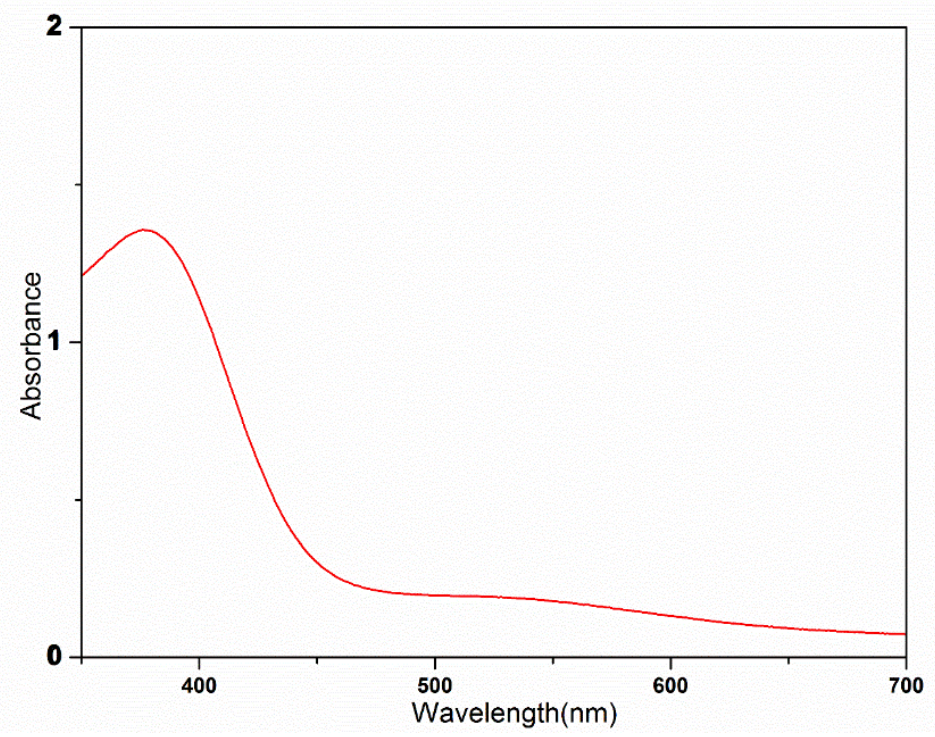

FIGURE 2. UV-vis absorption spectra of as-synthesized ZnO-NPs from Tecoma stans leaves extract

\subsection{XRD of $\mathrm{ZnO}$ nanoparticles}

The XRD analysis of the as-synthesized $\mathrm{ZnO}$-NPs from Tecoma stans leaf extract is shown in Figure 6.3. The sharp and narrow diffraction peaks indicate that the prepared $\mathrm{ZnO}-\mathrm{NPs}$ is well crystalline in nature. The diffraction peaks at $2 \theta$ values of $31.80^{\circ}, 34.75^{\circ}, 36.37^{\circ}, 47.77^{\circ}, 56.72^{\circ}$, $62.97^{\circ}, 66.25^{\circ}, 67.95^{\circ}$ and $69.11^{\circ}$ are observed with respect to (100), (002), (101), (102), (110),(103), (200), (112) and (201) with matching (JCPDS No. 36-1451) respectively in Figure 3. The mean crystallite size (D) of the NPs was calculated from the XRD line broadening measurement using Debye-Scherer's formula (1), 
$D=0.89 \lambda /(\beta \operatorname{Cos} \theta)$

Where $\lambda$ is the wavelength $(\mathrm{Cu} \mathrm{K} \alpha$ ), $\beta$ is the full width half-maximum (FWHM) of the $\mathrm{ZnO}$ (101) line and $\theta$ is the diffraction angle. The calculated crystallite size is $20.42 \mathrm{~nm}$. The crystalline nature, particle size and the phase form confirmation was further studied from HR-TEM [40].

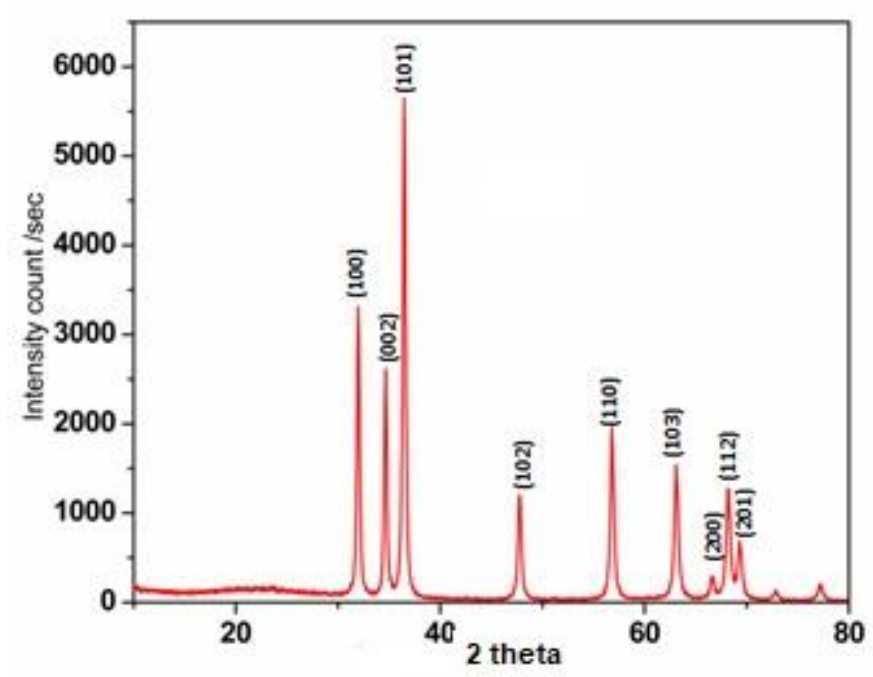

FIGURE 3. X-ray diffraction profile of biosynthesized ZnO-NPs from Tecoma stans leaves extract

\subsection{FT-IR Analysis}

FTIR analysis is carried out usually to find out the presence of functional groups and possible relationships between plant biomolecules and metals also to measure the IR radiation absorbed by the synthesized nanoparticles against the wavelength. FT-IR spectra of Tecoma stans leaf extract and as-synthesized ZnO-NPs has been shown in Figure 4. The FT-IR estimations confirmed the presence of biomolecules present in the leaf extract. Prominent peaks at 3282 and $3302 \mathrm{~cm}^{-1}$ are because of the extending vibrations of $\mathrm{O}-\mathrm{H}$ in alcohols and phenolic mixes and $\mathrm{N}-\mathrm{H}$ in auxiliary amides. The groups at 1642 and $1638 \mathrm{~cm}^{-1}$ are for amide I and amide II groups, respectively. The groups at 2120 and $2126 \mathrm{~cm}^{-1}$ are due to alkynyl C-C stretching aromatic stretching bands of the various bioactive compounds. Generally, metal oxides are characterized by intrinsic absorption 
bands below $1000 \mathrm{~cm}^{-1}$ (the so-called fingerprint region) due to inter-atomic vibrations; hence, accordingly, the less intense peak at $798 \mathrm{~cm}^{-1}$ identify the presence of ZnO-NPs (Figure 4a) [41].

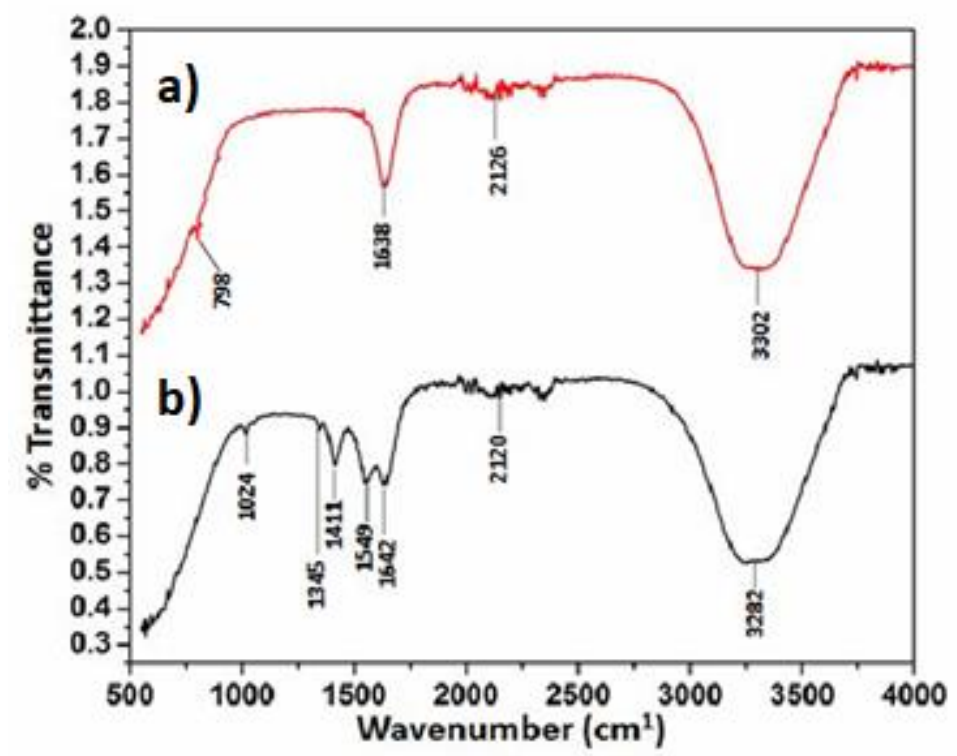

FIGURE 4. FT-IR spectrum of biosynthesized (a) assynthesized ZnO-NPs and (b) Tecoma stans leaves extract

\subsection{TEM Analysis}

The crystalline nature and the size of the particles of synthesized ZnO-NPs (after calcination at $700^{\circ} \mathrm{C}$ for $3 \mathrm{~h}$ ) was studied by TEM [42]. The TEM images at different magnifications and selected area electron diffraction (SAED) patterns are depicted in Figure 5. The TEM image showed that the synthesized $\mathrm{ZnO}-\mathrm{NPs}$ are well dispersed and are mostly triangular in shape with particle size range from 15 to $20 \mathrm{~nm}$. The SAED pattern confirmed the crystalline nature of the nanoparticles. The nanoparticles size distribution graph is depicted in Figure $5 f$. 

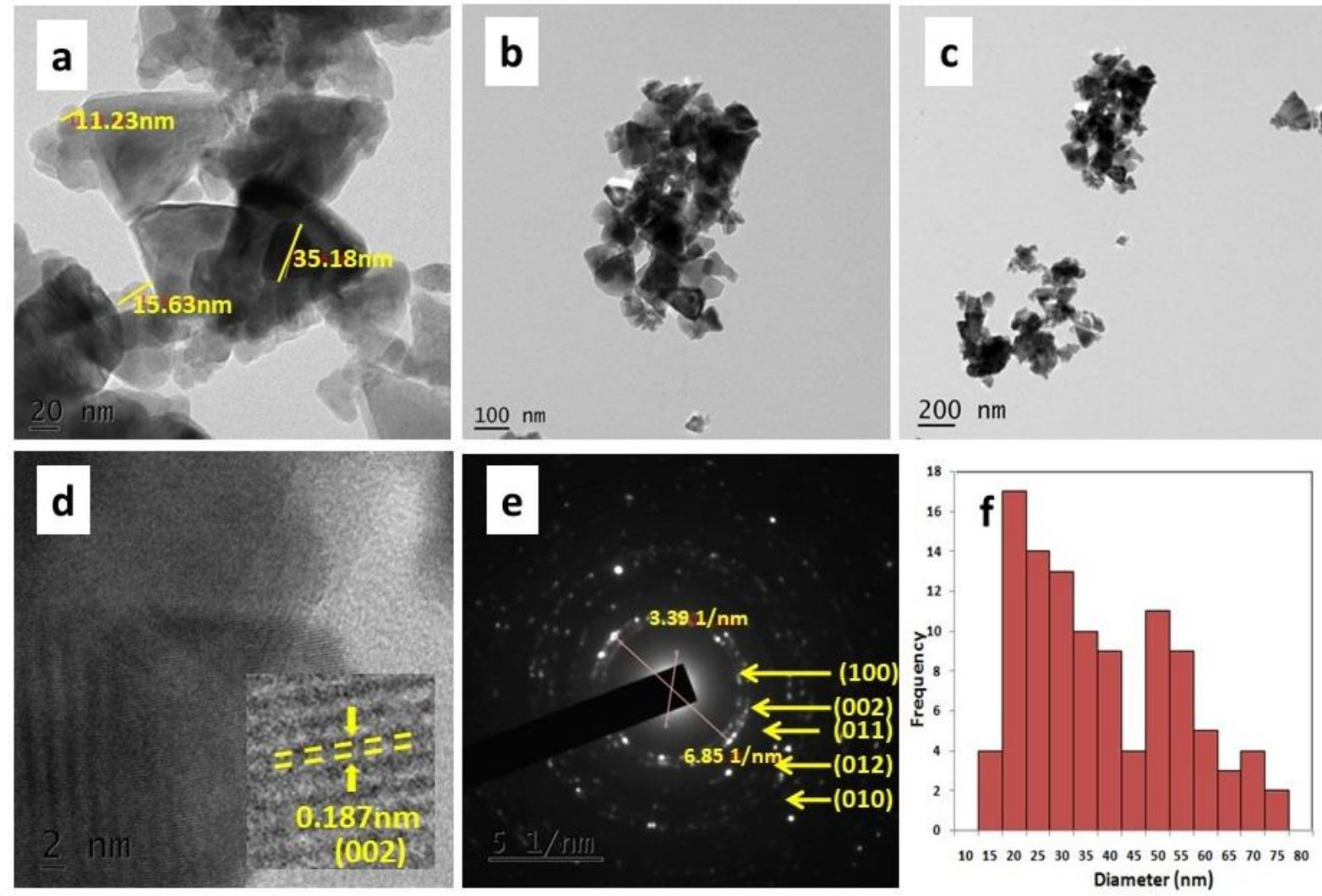

FIGURE 5. (a-c) TEM images at 20, 100 and $200 \mathrm{~nm}$ scale, (d) HRTEM image at $2 \mathrm{~nm}$ scale and (e) SAED pattern and (f) nanoparticles size distribution graph of biosynthesized ZnO-NPs from Tecoma stans leaves extract

\subsection{SEM-EDX analysis}

The SEM images confirmed the triangular shape, well dispersed nanoparticles with average 15-20 $\mathrm{nm}$ sized nanoparticles and a mean size of $20.42 \mathrm{~nm}$ (Figure 6a). To study the chemical composition and further information of the metallic nature of the synthesized nanoparticles, we have studied the EDX [43]. In this study generally interaction takes place between X-rays and the compound to be investigated which results in reflection of the peak of metal or compounds present in the sample. The obtained peak amplitude shows the presence of particular elements in the compound. The EDX analysis with elemental compositions of the synthesized ZnO-NPs is depicted in Figure 6b. 

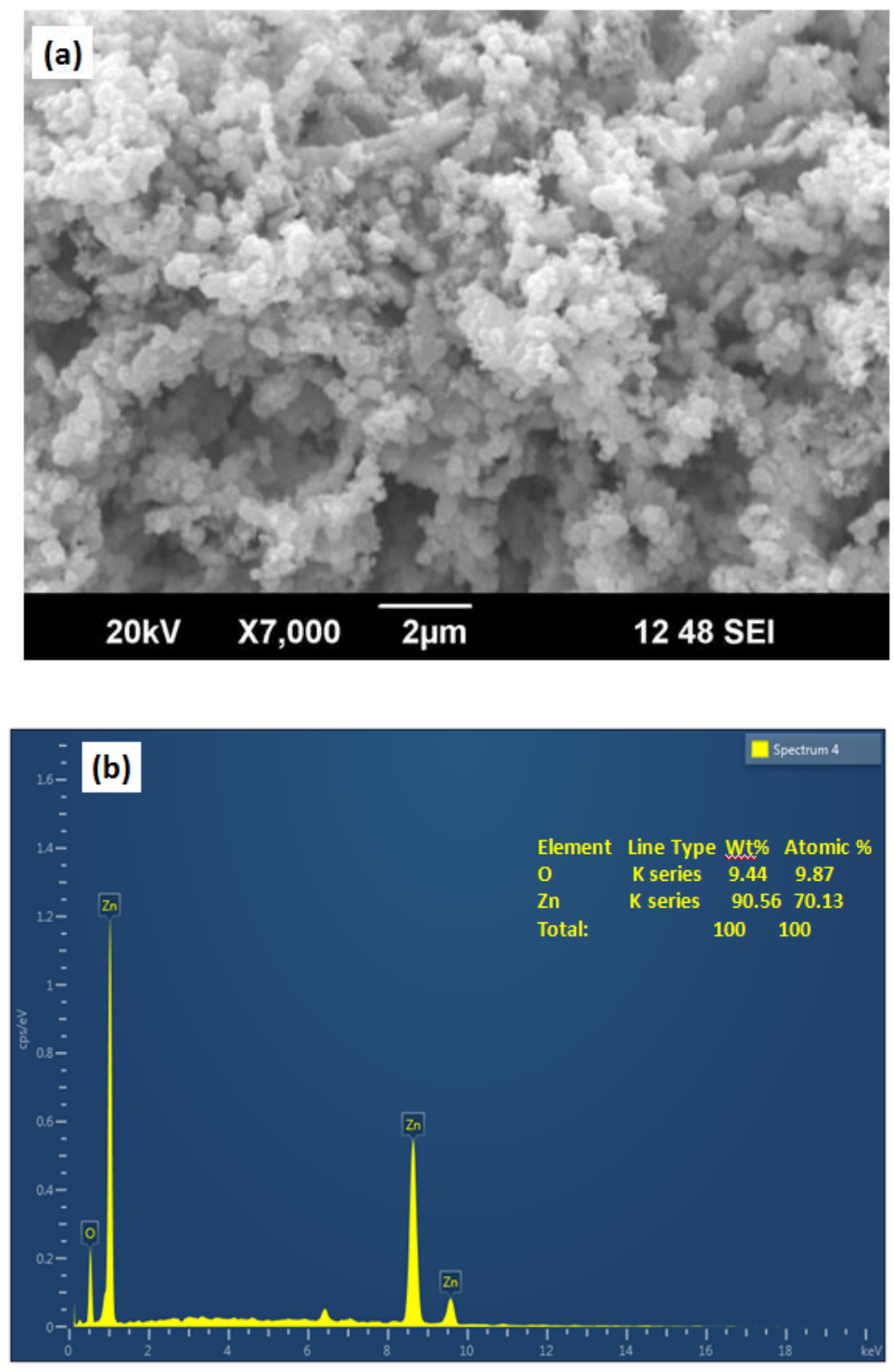

FIGURE 6. (a) SEM (b) EDX analysis of biosynthesized ZnO-NPs from Tecoma stans leaves extract

\subsection{XPS analysis}

The XPS analysis is used to identify the surface elements of the sample and results of the analysis is illustrated in Figure 7. The XPS spectrum revealed the presence of $\mathrm{Zn}$ and $\mathrm{O}$ in the sample. Small amount of carbon seen in Figure 1a is due to hydrocarbon from plant extract residues. The oxygen spectrum deconvoluted into two parts as shown in Figure 7c, the peak at $530.01 \mathrm{eV}$ is attributed to $\mathrm{O}^{2-}$ from $\mathrm{ZnO}$ and peak at $531.89 \mathrm{eV}$ is due to sample surface adsorbed water and $\mathrm{O}_{2}$. 
From Figure 1c, the peaks obtained at 1021.5 and $1044.6 \mathrm{eV}$ for $\mathrm{Zn} 2 \mathrm{p}_{3 / 2}$ and $\mathrm{Zn} 2 \mathrm{p}_{1 / 2}$ respectively are attributed to $\mathrm{Zn}$ ions bonded to $\mathrm{O}$ ions [44].
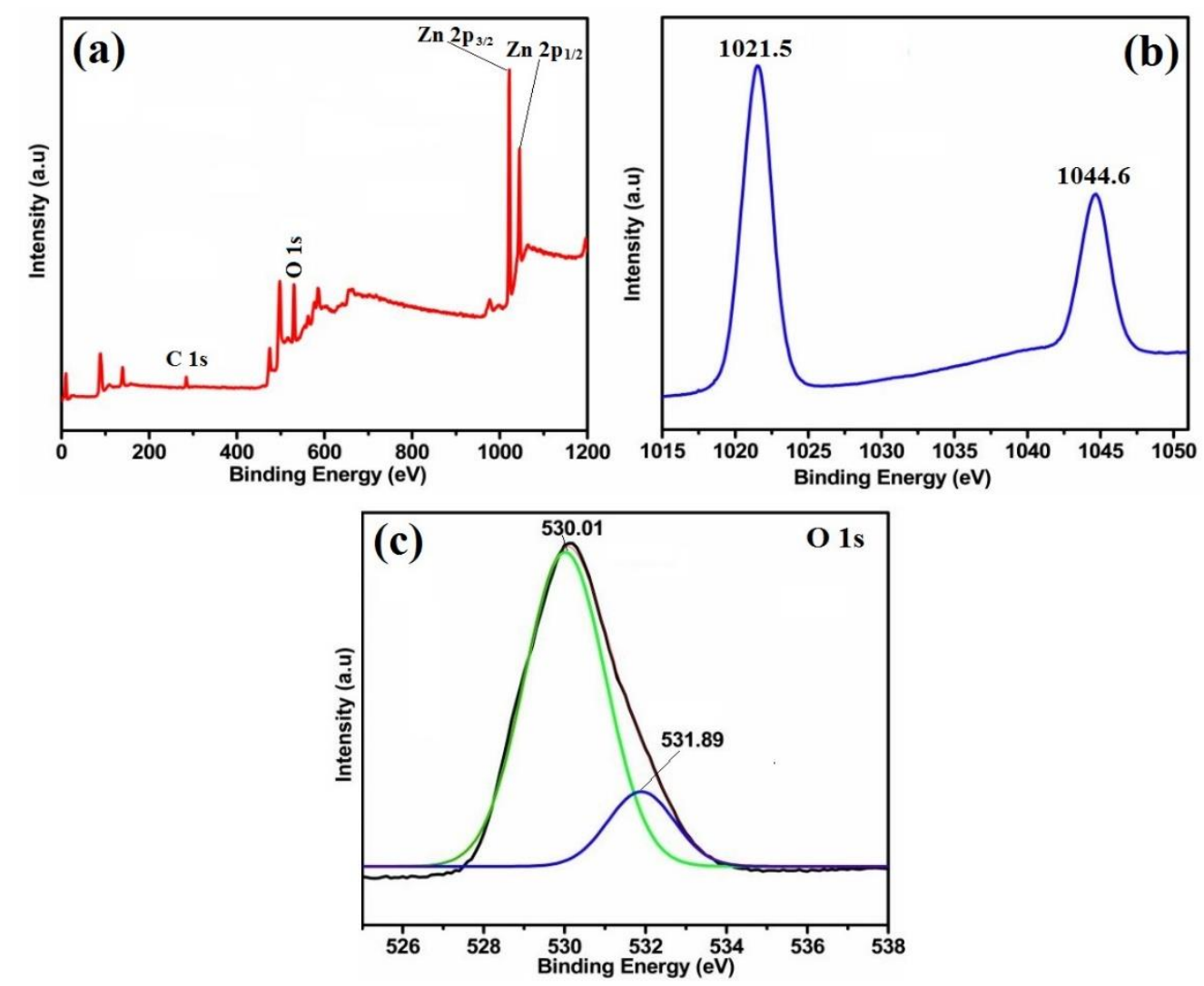

FIGURE 7. XPS analysis of biosynthesized ZnO-NPs from Tecoma stans leaves extract 


\subsection{TGA analysis}

In Figure 8, the TG curve of the as-synthesized ZnO-NPs shows a gradual weight loss from 90$100{ }^{\circ} \mathrm{C}$ due to the evaporation of water present in the nanoparticles and continuous weight loss occurred between $250-650{ }^{\circ} \mathrm{C}$. Later, a plateau region is formed at a temperature above $650{ }^{\circ} \mathrm{C}$ which confirmed the formation of highly stable $\mathrm{ZnO}-\mathrm{NPs}$. Hence, calcined at a temperature of 700 ${ }^{\circ} \mathrm{C}$ and above seems to guarantee the formation of stable $\mathrm{ZnO}-\mathrm{NPs}$. Accordingly, we have calcined the as-synthesized $\mathrm{ZnO}-\mathrm{NPs}$ at a temperature of $700{ }^{\circ} \mathrm{C}$ for $3 \mathrm{~h}$.

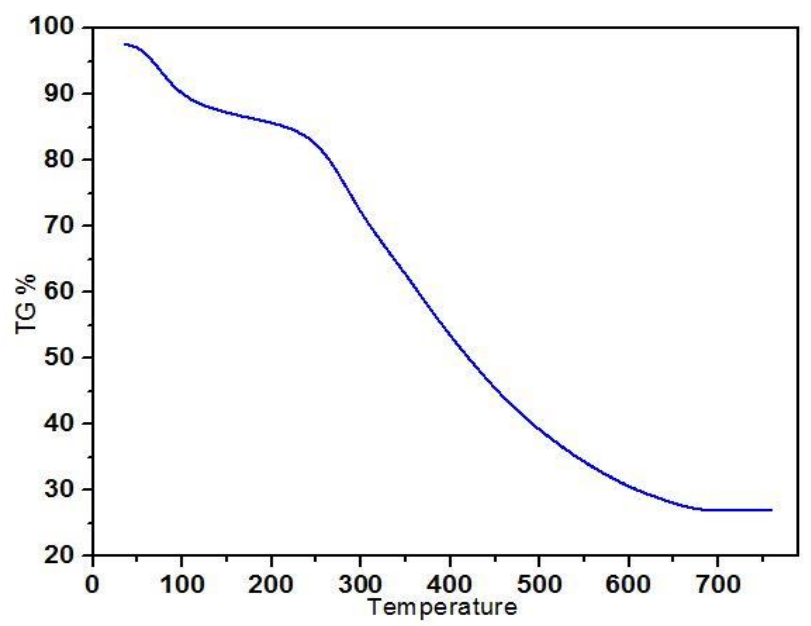

FIGURE 8. TGA analysis of biosynthesized ZnO-

NPs from Tecoma stans leaves extract

\subsection{Photoluminescence Study}

Photoluminescence (PL) studies were performed to emphasize its emission properties as shown in Figure 9. The photoluminescence of $\mathrm{ZnO}$ sample suggested a sharp emission of blue band at 447 $\mathrm{nm}$ have been observed from the prepared $\mathrm{ZnO}$-NPs sample may be in correlation with the defect structure in $\mathrm{ZnO}$ crystal [45]. 


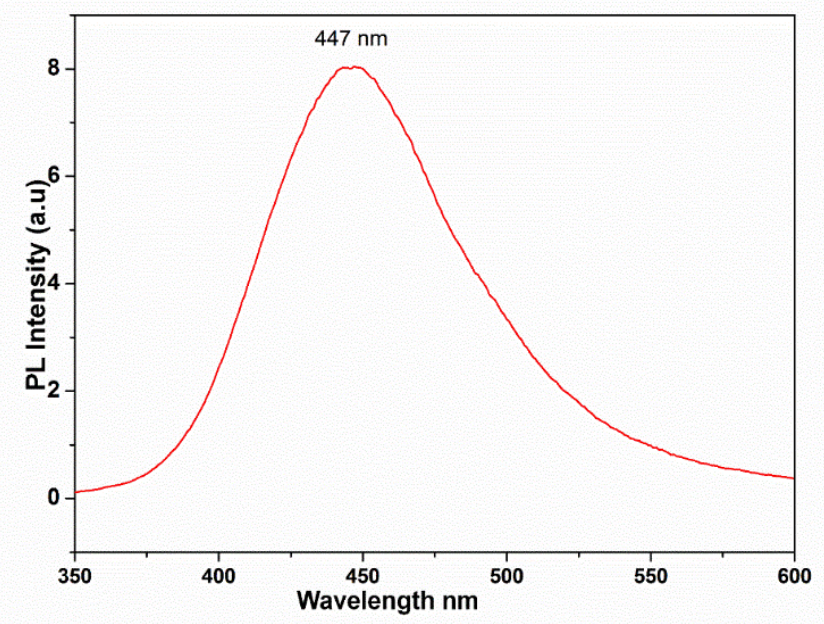

FIGURE 9. Photoluminescence analysis of $\mathrm{ZnO}-$

NPs from Tecoma stans leaves extract

\subsection{Antimicrobial activity}

Antimicrobial activity was performed by agar well diffusion method, with slight modifications. Freshly prepared molten Muller Hinton Agar (MHA) media for bacterial culture and Potato Dextrose Agar (PDA) media for fungal culture were poured to uniform depth of $5 \mathrm{~mm}$ and allowed to cool at room temperature [46],[47],[48]. After solidification, wells were made in MHA media by $6 \mathrm{~mm}$ sterilized cork borer. 1-2 drops of media were poured in the bottom with the help of sterile micropipette. $1-2 \times 10^{7} \mathrm{cfu} / \mathrm{mL}$ of test microorganisms were spread on the surface of MHA media using a glass spreader. $50 \mu \mathrm{L}$ of $\mathrm{ZnO}-\mathrm{NPs}$ of three different concentrations (1.0 mM, 0.5 $\mathrm{mM}$ and $0.25 \mathrm{mM}$ ) were then filled in three wells. DMSO was also used as negative control. The plates were then incubated for $24 \mathrm{~h}$ at $37{ }^{\circ} \mathrm{C}$ for bacterial culture and $48 \mathrm{~h}$ at $25{ }^{\circ} \mathrm{C}$ for fungal culture.

The antibacterial activity of $\mathrm{ZnO}-\mathrm{NPs}$ was evaluated by measuring the zone of inhibition (ZOI) in millimeter. ZnO-NPs displayed a very high antibacterial activity as shown in Figure 10 and Figure 11 and Table 1 and was found that Achromobacter spanius strain GCCSB1 showed highest ZOI of $24 \mathrm{~mm}$ at $1.0 \mathrm{mM}, 11 \mathrm{~mm}$ at $0.5 \mathrm{mM}$ and $5 \mathrm{~mm}$ at $0.25 \mathrm{mM}$, followed by Acinetobacter johnsonii strain SB_SK $22 \mathrm{~mm}$ at $1.0 \mathrm{mM}, 17 \mathrm{~mm}$ at $0.5 \mathrm{mM}$ and $0 \mathrm{~mm}$ at 0.25 $\mathrm{mM}$, Achromobacter xylosoxidans GCC582 showing $20 \mathrm{~mm}$ at $1.0 \mathrm{mM}, 18 \mathrm{~mm}$ at $0.5 \mathrm{mM}$, and $12 \mathrm{~mm}$ at $0.25 \mathrm{mM}$, Chromobacterium pseudoviolaceum strain GCC-SO4 showing $20 \mathrm{~mm}$ at 1.0 
$\mathrm{mM}, 12 \mathrm{~mm}$ at $0.5 \mathrm{mM}$, and $7 \mathrm{~mm}$ at $0.25 \mathrm{mM}$ and Bacillus cereus strain SN_SA showing the least among the five bacterial strains with $17 \mathrm{~mm} \mathrm{ZOI} \mathrm{at} 1.0 \mathrm{mM}, 6 \mathrm{~mm}$ at $0.5 \mathrm{mM}$, and no inhibition was observed at $0.25 \mathrm{mM}$.
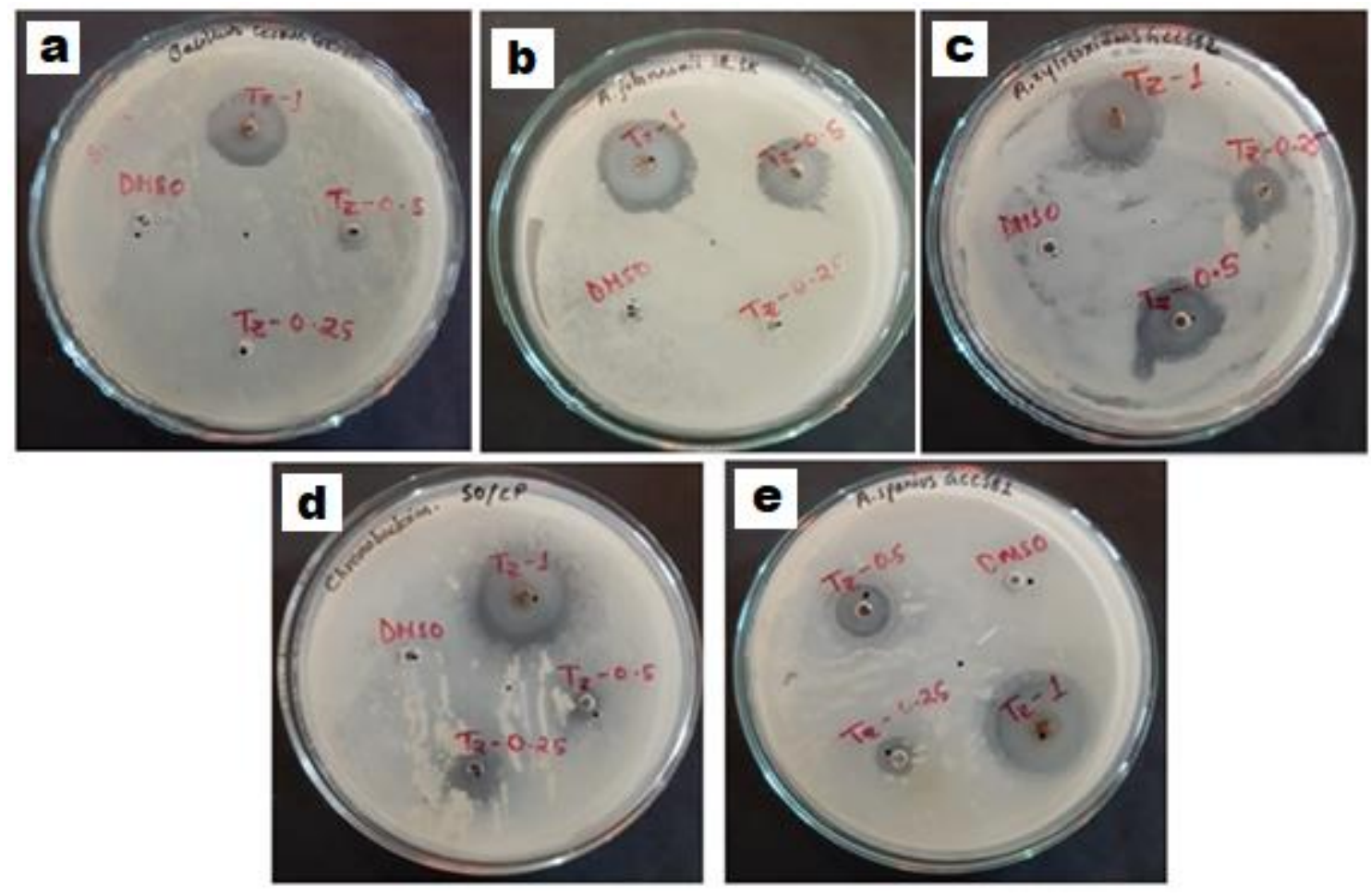

FIGURE 10. ZOI caused by ZnO-NPs against five pathogenic bacteria: a) Bacillus cereus, b) Acinetobacter johnsonii strain SB_SK, c) Achromobacter xylosoxidans GCC582, d) Chromobacterium pseudoviolaceum strain GCC-SO4. e) Achromobacter spanius strain GCCSB1. (i) $0.25 \mathrm{mM}$ (ii) $0.5 \mathrm{mM}$ (iii) $1 \mathrm{mM}$ 


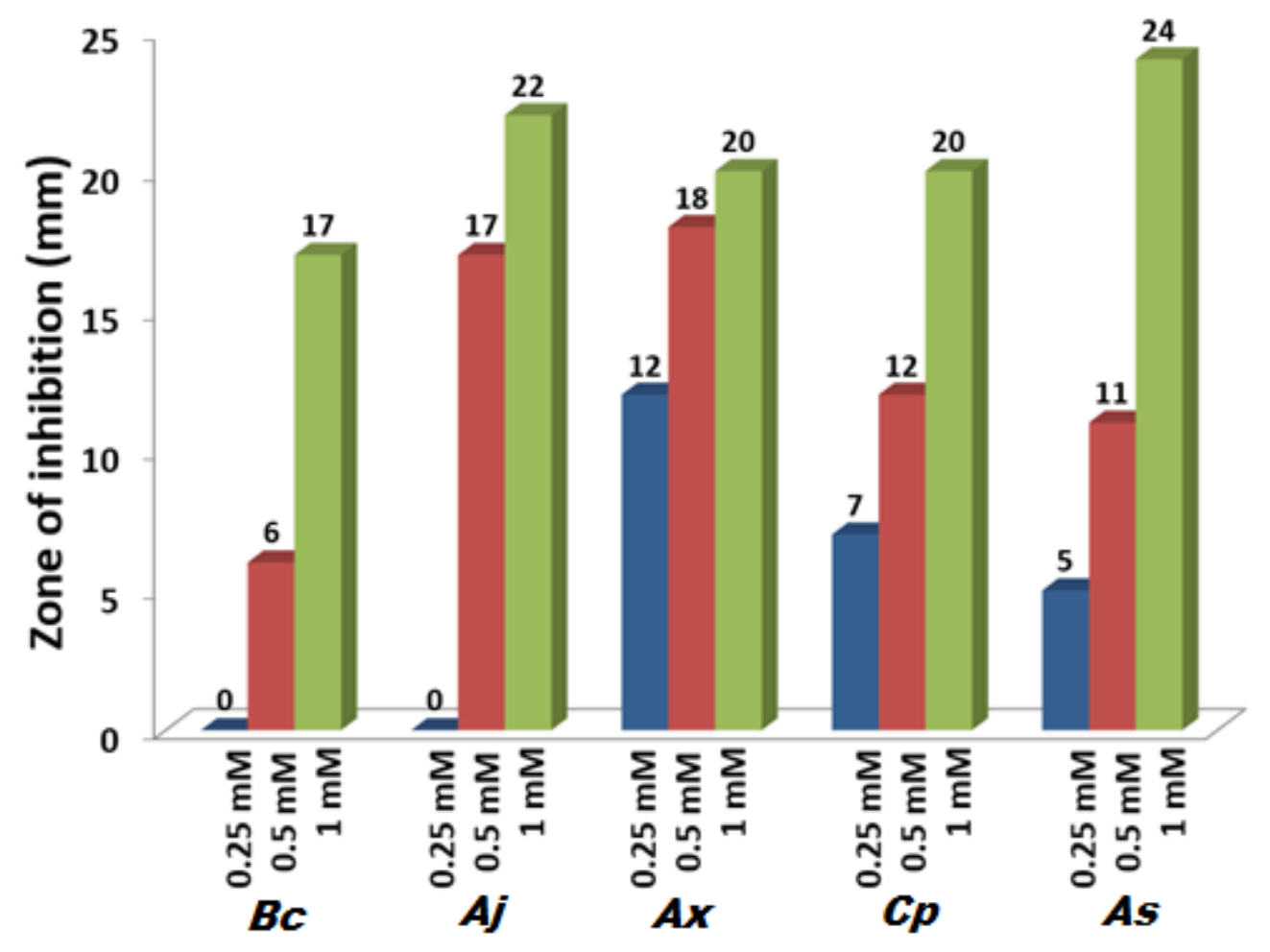

FIGURE 11. Antibacterial activities of $\mathrm{ZnO}-\mathrm{NPs}$ at different concentrations against five pathogenic bacteria; a) Bacillus cereus strain SN_SA, b) Acinetobacter johnsonii strain SB_SK, c) Achromobacter xylosoxidans GCC582, d) Achromobacter spanius strain GCCSB1, e) Chromobacterium pseudoviolaceum strain GCC-SO4)

Table 1: Antibacterial activity of $\mathrm{ZnO}-\mathrm{NPs}$ against five pathogenic bacteria at three concentrations

\begin{tabular}{lllll}
\hline Test microorganisms & Test sample & Test sample & Test sample & Control \\
\hline Bacterial isolates & $1.0 \mathrm{mM}$ & $0.5 \mathrm{mM}$ & $0.25 \mathrm{MM}$ & DMSO \\
\hline $\begin{array}{l}\text { 1. Bacillus cereus strain } \\
\quad 17\end{array}$ & 6 & 0 & 0 \\
$\quad$ SN_SA & 22 & 17 & 0 & 0 \\
2. Acinetobacter johnsonii & & & \\
$\quad$ strain SB_SK & & 18 & 0
\end{tabular}




\begin{tabular}{lcccc}
\hline 4. $\begin{array}{l}\text { Chromobacterium } \\
\text { pseudoviolaceum strain }\end{array}$ & 20 & 12 & 7 & \\
GCC-SO4 & & & & \\
5. Achromobacter spanius & 24 & 11 & 5 & 0 \\
strain GCCSB1 & & & \\
\hline
\end{tabular}

The antifungal activity of ZnO-NPs was also evaluated which also displayed very high antifungal activity as shown in Figure 12, Figure 13 and Table 1 and was found that among the four fugal strain studied for antifungal activity the Penicillium citirinum, showing $30 \mathrm{~mm}$ ZOI at $1.0 \mathrm{mM}, 22 \mathrm{~mm}$ at $0.5 \mathrm{mM}$, and $11 \mathrm{~mm}$ at $0.25 \mathrm{mM}$, followed by Candida albicans showing 19 $\mathrm{mm}$ at $1.0 \mathrm{mM}, 14 \mathrm{~mm}$ at $0.5 \mathrm{mM}$, and $9 \mathrm{~mm}$ at $0.25 \mathrm{mM}$, Fusarium oxysporium showing $18 \mathrm{~mm}$ at $1.0 \mathrm{mM}, 12 \mathrm{~mm}$ at $0.5 \mathrm{mM}$, and $10 \mathrm{~mm}$ at $0.25 \mathrm{mM}$, and Aspergillus niger showing the least antifungal activity $14 \mathrm{~mm}$ at $1.0 \mathrm{mM}, 10 \mathrm{~mm}$ at $0.5 \mathrm{mM}$, and $8 \mathrm{~mm}$ at $0.25 \mathrm{mM}$ respectively.

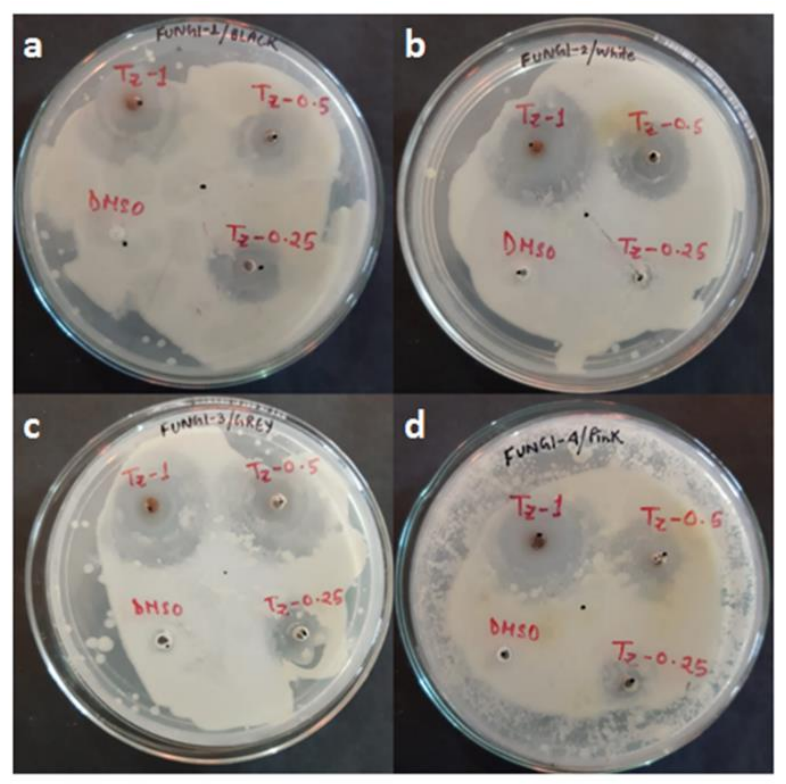

FIGURE 12. ZOI caused by $\mathrm{ZnO}-\mathrm{NPs}$ against four pathogenic fungi; a) Aspergillus niger, b) Penicillium citirinum c) Fusarium oxysporium, d) Candida albicans (i) $0.25 \mathrm{mM}$ (ii) $0.5 \mathrm{mM}$ (iii) $1 \mathrm{mM}$ 


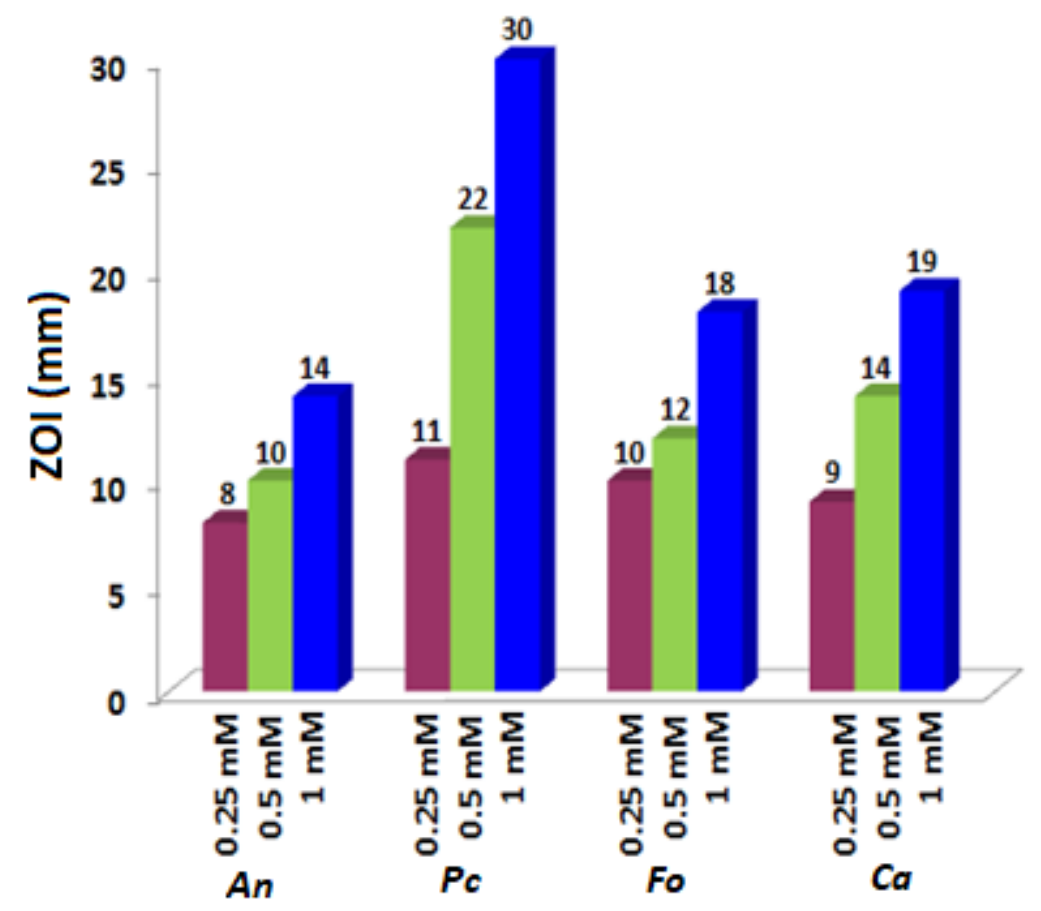

Figure 13. ZOI caused by ZnO-NPs against four pathogenic fungi a) Aspergillus niger b) Penicillium citirinum c) Fusarium oxysporium d) Candida albicans at concentration

Table 2: Antifungal activity of measurement of ZOI against pathogenic fungi

\begin{tabular}{lllll}
\hline Test microorganisms & Test sample & Test sample & Test sample & Control \\
\hline Fungal isolates & $1.0 \mathrm{mM}$ & $0.5 \mathrm{mM}$ & $0.25 \mathrm{mM}$ & DMSO \\
\hline 1. Aspergillus niger & 14 & 10 & 8 & 0 \\
2. Penicillium citirinum & 30 & 22 & 11 & 0 \\
3. Fusarium oxysporium & 18 & 12 & 10 & 0 \\
4. Candida albicans & 19 & 14 & 9 & 0 \\
\hline
\end{tabular}

\section{Conclusion}

Herein, we reported a facile biosynthesis of zinc oxide nanoparticles were synthesized using Tecoma stans leaf extract. The XRD and TEM investigation demonstrated of the crystalline nature 
and triangular shape of $\mathrm{ZnO}$ nanoparticles, respectively. The band hole of the $\mathrm{ZnO}-\mathrm{NPs}$ was evaluated from the UV-vis assimilation, and it was seen that there was a sharp move in the ingestion edge with increase in temperature. From the TEM images, the average size of the $\mathrm{ZnO}$ NPs was observed as $20.42 \mathrm{~nm}$. The peaks obtained at 1021.5 and 1044.6 for $\mathrm{Zn} \mathrm{2p}$ 3/2and Zn 2p $\frac{1}{2}$ respectively in the XPS analysis were attributed to $\mathrm{Zn}$ ions bond with $\mathrm{O}$ ions. The synthesized $\mathrm{ZnO}-\mathrm{NPs}$ showed a very high antibacterial and antifungal property attributed to the excellent edges fitting of the synthesized triangular shape nanoparticles to the cell wall of the tested microorganisms.

\section{Acknowledgment}

This work is funded by SERB, New Delhi (grant nos. SB/FT/CS-103/2013 and SB/EMEQ076/2014).

\section{Reference}

[1] Johnson S. Nanotechnology. Encycl. Appl. Ethics, 2012:182-185. https://doi.org/10.1016/B978-0-12-373932-2.00044-2.

[2] Mahalik NP. Micromanufacturing and nanotechnology. Springer, Berlin, Heidelberg 2006. https://doi.org/10.1007/3-540-29339-6.

[3] Koppens FHL, Mueller T, Avouris P, Ferrari AC, Vitiello MS, Polini M. Photodetectors based on graphene, other two-dimensional materials and hybrid systems. Nat Nanotechnol 2014;9:780-793. https://doi.org/10.1038/nnano.2014.215.

[4] Dong Y, He K, Yin L, Zhang A. A facile route to controlled synthesis of Co3O4 nanoparticles and their environmental catalytic properties. Nanotechnology 2007;18. https://doi.org/10.1088/0957-4484/18/43/435602.

[5] Rajkumari K, Kalita J, Das D, Rokhum L. Magnetic Fe3O4@silica sulfuric acid nanoparticles promoted regioselective protection/deprotection of alcohols with dihydropyran under solvent-free conditions. RSC Adv 2017;7:56559-65. https://doi.org/10.1039/c7ra12458a.

[6] Hann S, Raja R, Somorjai GA, Zhou DB, editors. Nanotechnology in catalysis. Springer; 
2007.Nanotechnology in Catalysis. 2007. https://doi.org/10.1007/978-0-387-34688-5.

[7] Pathak G, Rajkumari K, Rokhum L. Wealth from waste:: M. acuminata peel wastederived magnetic nanoparticles as a solid catalyst for the Henry reaction. Nanoscale Adv 2019;1:1013-20. https://doi.org/10.1039/c8na00321a.

[8] Sun C, Lee JSH, Zhang M. Magnetic nanoparticles in MR imaging and drug delivery. Adv Drug Deliv Rev 2008;60:1252-1265. https://doi.org/10.1016/j.addr.2008.03.018.

[9] Farokhzad OC, Langer R. Impact of nanotechnology on drug delivery. ACS Nano 2009;3:16-20.. https://doi.org/10.1021/nn900002m.

[10] Farokhzad OC, Langer R. Impact of nanotechnology on drug delivery. ACS Nano 2009. https://doi.org/10.1021/nn900002m.

[11] Zare M, Namratha K, Thakur MS, Byrappa K. Biocompatibility assessment and photocatalytic activity of bio-hydrothermal synthesis of $\mathrm{ZnO}$ nanoparticles by Thymus vulgaris leaf extract. Mater Res Bull 2019;109:49-59. https://doi.org/10.1016/j.materresbull.2018.09.025.

[12] Abboud Z, Vivekanandhan S, Misra M, Mohanty AK. Leaf extract mediated biogenic process for the decoration of graphene with silver nanoparticles. Mater Lett 2016;178:115-9. https://doi.org/10.1016/j.matlet.2016.04.120.

[13] Berry CC. Progress in functionalization of magnetic nanoparticles for applications in biomedicine. J Phys D Appl Phys 2009;42. https://doi.org/10.1088/0022$3727 / 42 / 22 / 224003$.

[14] Vanlalveni C, Rajkumari K, Biswas A, Adhikari PP, Lalfakzuala R, Rokhum L. Green Synthesis of Silver Nanoparticles Using Nostoc linckia and its Antimicrobial Activity: a Novel Biological Approach. Bionanoscience 2018;8:624-31. https://doi.org/10.1007/s12668-018-0520-9.

[15] Diallo A, Ngom BD, Park E, Maaza M. Green synthesis of $\mathrm{ZnO}$ nanoparticles by Aspalathus linearis: Structural \& optical properties. J Alloys Compd 2015;646:425-30. https://doi.org/10.1016/j.jallcom.2015.05.242. 
[16] Nadeem M, Abbasi BH, Younas M, Ahmad W, Khan T. A review of the green syntheses and anti-microbial applications of gold nanoparticles. Green Chem Lett Rev 2017;10:216227. https://doi.org/10.1080/17518253.2017.1349192.

[17] Banerjee P, Satapathy M, Mukhopahayay A, Das P. Leaf extract mediated green synthesis of silver nanoparticles from widely available Indian plants: Synthesis, characterization, antimicrobial property and toxicity analysis. Bioresour Bioprocess 2014;1. https://doi.org/10.1186/s40643-014-0003-y.

[18] Xu D, Fan D, Shen W. Catalyst-free direct vapor-phase growth of Zn1-xCuxO microcross structures and their optical properties. Nanoscale Res Lett 2013;8:1-9. https://doi.org/10.1186/1556-276X-8-46.

[19] Agarwal H, Venkat Kumar S, Rajeshkumar S. A review on green synthesis of zinc oxide nanoparticles - An eco-friendly approach. Resour Technol 2017;3:406-13. https://doi.org/10.1016/j.reffit.2017.03.002.

[20] Thatoi P, Kerry RG, Gouda S, Das G, Pramanik K, Thatoi H, et al. Photo-mediated green synthesis of silver and zinc oxide nanoparticles using aqueous extracts of two mangrove plant species, Heritiera fomes and Sonneratia apetala and investigation of their biomedical applications. J Photochem Photobiol B Biol 2016;163:311-8. https://doi.org/10.1016/j.jphotobiol.2016.07.029.

[21] Espitia PJP, Soares N de FF, Coimbra JS dos R, de Andrade NJ, Cruz RS, Medeiros EAA. Zinc Oxide Nanoparticles: Synthesis, Antimicrobial Activity and Food Packaging Applications. Food Bioprocess Technol 2012;5:1447-64. https://doi.org/10.1007/s11947012-0797-6.

[22] Al-Naamani L, Dobretsov S, Dutta J. Chitosan-zinc oxide nanoparticle composite coating for active food packaging applications. Innov Food Sci Emerg Technol 2016;38:231-7. https://doi.org/10.1016/j.ifset.2016.10.010.

[23] Venkatachalam P, Priyanka N, Manikandan K, Ganeshbabu I, Indiraarulselvi P, Geetha N, et al. Enhanced plant growth promoting role of phycomolecules coated zinc oxide nanoparticles with P supplementation in cotton (Gossypium hirsutum L.). Plant Physiol 
Biochem 2017;110:118-27. https://doi.org/10.1016/j.plaphy.2016.09.004.

[24] Ali K, Dwivedi S, Azam A, Saquib Q, Al-Said MS, Alkhedhairy AA, et al. Aloe vera extract functionalized zinc oxide nanoparticles as nanoantibiotics against multi-drug resistant clinical bacterial isolates. J Colloid Interface Sci 2016;472:145-56. https://doi.org/10.1016/j.jcis.2016.03.021.

[25] Kundu D, Hazra C, Chatterjee A, Chaudhari A, Mishra S. Extracellular biosynthesis of zinc oxide nanoparticles using Rhodococcus pyridinivorans NT2: Multifunctional textile finishing, biosafety evaluation and in vitro drug delivery in colon carcinoma. J Photochem Photobiol B Biol 2014;140:194-204. https://doi.org/10.1016/j.jphotobiol.2014.08.001.

[26] Vimala K, Sundarraj S, Paulpandi M, Vengatesan S, Kannan S. Green synthesized doxorubicin loaded zinc oxide nanoparticles regulates the Bax and Bcl-2 expression in breast and colon carcinoma. Process Biochem 2014;49:160-72. https://doi.org/10.1016/j.procbio.2013.10.007.

[27] Ramesh M, Anbuvannan M, Viruthagiri G. Green synthesis of $\mathrm{ZnO}$ nanoparticles using Solanum nigrum leaf extract and their antibacterial activity. Spectrochim Acta - Part A Mol Biomol Spectrosc 2015;136:864-70. https://doi.org/10.1016/j.saa.2014.09.105.

[28] Sirelkhatim A, Mahmud S, Seeni A. Review on Zinc Oxide Nanoparticles : Antibacterial Activity and Toxicity Mechanism. Nano-Micro Lett 2015;7:219-42. https://doi.org/10.1007/s40820-015-0040-x.

[29] Karnan T, Selvakumar SAS. Biosynthesis of $\mathrm{ZnO}$ nanoparticles using rambutan (Nephelium lappaceumL.) peel extract and their photocatalytic activity on methyl orange dye. J Mol Struct 2016;1125: 358-365. https://doi.org/10.1016/j.molstruc.2016.07.029.

[30] Basnet P, Inakhunbi Chanu T, Samanta D, Chatterjee S. A review on bio-synthesized zinc oxide nanoparticles using plant extracts as reductants and stabilizing agents. J Photochem Photobiol B Biol 2018;183:201-21. https://doi.org/10.1016/j.jphotobiol.2018.04.036.

[31] Cha SH, Hong J, McGuffie M, Yeom B, Vanepps JS, Kotov NA. Shape-Dependent Biomimetic Inhibition of Enzyme by Nanoparticles and Their Antibacterial Activity. ACS 
Nano 2015;9:9097-105. https://doi.org/10.1021/acsnano.5b03247.

[32] Kim I, Worthen AJ, Johnston KP, DiCarlo DA, Huh C. Size-dependent properties of silica nanoparticles for Pickering stabilization of emulsions and foams. J Nanoparticle Res 2016;18:1-12. https://doi.org/10.1007/s11051-016-3395-0.

[33] Gilbertson LM, Albalghiti EM, Fishman ZS, Perreault F, Corredor C, Posner JD, et al. Shape-Dependent Surface Reactivity and Antimicrobial Activity of Nano-Cupric Oxide. Environ Sci Technol 2016;50:3975-84. https://doi.org/10.1021/acs.est.5b05734.

[34] Orendorff CJ, Sau TK, Murphy CJ. Shape-dependent plasmon-resonant gold nanoparticles. Small 2006;2:636-9. https://doi.org/10.1002/smll.200500299.

[35] Narayanan R, El-Sayed MA. Shape-dependent catalytic activity of platinum nanoparticles in colloidal solution. Nano Lett 2004;4:1343-8. https://doi.org/10.1021/n10495256.

[36] Park T, Papaefthymiou GC, Viescas AJ, Moodenbaugh AR, Wong SS. Size-Dependent Magnetic Properties of Nanoparticles 2007;7:766-772. https://doi.org/10.1021/nl063039w.

[37] Seo WS, Jo HH, Lee K, Kim B, Oh SJ, Park JT. Size-dependent magnetic properties of colloidal Mn3O4 and MnO nanoparticles. Angew Chemie - Int Ed 2004;43:1115-7. https://doi.org/10.1002/anie.200352400.

[38] Qu J, Yuan X, Wang X, Shao P. Zinc accumulation and synthesis of ZnO nanoparticles using Physalis alkekengi L. Environ Pollut 2011;159:1783-8. https://doi.org/10.1016/j.envpol.2011.04.016.

[39] Ni YH, Wei XW, Hong JM, Ye Y. Hydrothermal preparation and optical properties of ZnO nanorods. Mater Sci Eng B Solid-State Mater Adv Technol 2005;121:42-7. https://doi.org/10.1016/j.mseb.2005.02.065.

[40] Kiran Kumar ABV, Saila ES, Narang P, Aishwarya M, Raina R, Gautam M, et al. Biofunctionalization and biological synthesis of the $\mathrm{ZnO}$ nanoparticles: The effect of Raphanus sativus (white radish) root extract on antimicrobial activity against MDR strain for wound healing applications. Inorg Chem Commun 2019;100:101-6. 
https://doi.org/10.1016/j.inoche.2018.12.014.

[41] Fu L, Fu Z. Plectranthus amboinicus leaf extract-assisted biosynthesis of $\mathrm{ZnO}$ nanoparticles and their photocatalytic activity. Ceram Int 2015;41:2492-6. https://doi.org/10.1016/j.ceramint.2014.10.069.

[42] Abdul Salam H, Sivaraj R, Venckatesh R. Green synthesis and characterization of zinc oxide nanoparticles from Ocimum basilicum L. var. purpurascens Benth.-Lamiaceae leaf extract. Mater Lett 2014. https://doi.org/10.1016/j.matlet.2014.05.033.

[43] Chennimalai M, Do JY, Kang M, Senthil TS. A facile green approach of ZnO NRs synthesized via Ricinus communis L. leaf extract for Biological activities. Mater Sci Eng C 2019;103:109844. https://doi.org/10.1016/j.msec.2019.109844.

[44] Geetha MS, Nagabhushana H, Shivananjaiah HN. Green mediated synthesis and characterization of $\mathrm{ZnO}$ nanoparticles using Euphorbia Jatropa latex as reducing agent. J Sci Adv Mater Devices 2016;1:301-10. https://doi.org/10.1016/j.jsamd.2016.06.015.

[45] Nethravathi PC, Shruthi GS, Suresh D, Udayabhanu, Nagabhushana H, Sharma SC. Garcinia xanthochymus mediated green synthesis of $\mathrm{ZnO}$ nanoparticles: Photoluminescence, photocatalytic and antioxidant activity studies. Ceram Int 2015;41:8680-7. https://doi.org/10.1016/j.ceramint.2015.03.084.

[46] Biswas A, Vanlalveni C, Adhikari PP, Lalfakzuala R, Rokhum L. Biosynthesis, characterisation and antibacterial activity of Mikania micrantha leaf extract-mediated AgNPs. Micro Nano Lett 2019;14:799 - 803. https://doi.org/10.1049/mnl.2018.5661.

[47] Biswas A, Vanlalveni C, Adhikari PP, Lalfakzuala R, Rokhum L. Green biosynthesis, characterisation and antimicrobial activities of silver nanoparticles using fruit extract of Solanum viarum. IET Nanobiotechnology 2018;12:933 - 938. https://doi.org/10.1049/ietnbt.2018.0050.

[48] Biswas A, Chawngthu L, Vanlalveni C, Hnamte R, Lalfakzuala R, Rokhum L. Biosynthesis of silver nanoparticles using selaginella bryopteris plant extracts and studies of their antimicrobial and photocatalytic activities. J Bionanoscience 2018;12:227-32. 
https://doi.org/10.1166/jbns.2018.1510. 